\title{
SEVENTY YEARS OF THE SECTION FOR THE HISTORY OF MEDICINE OF THE SERBIAN MEDICAL SOCIETY
}

\author{
Zoran Vacić ${ }^{1}$ \\ ${ }^{1}$ Akademija medicinskih nauka Srpskog lekarskog društva, \\ Beograd, Srbija \\ ${ }^{1}$ Academy of Medical Sciences of the Serbian Medical Society, \\ Belgrade, Serbia
}

\section{SAŽETAK}

U radu je obrađeno osnivanje sekcija Srpskog lekarskog društva u periodu do 1950. godine kao i izmene Pravila Srpskog lekarskog društva 1919. i 1928. godine. Pre Prvog svetskog rata osnovana je Sekcija za tuberkulozu (1907). U međuratnom periodu osnovano je sedam specijalističkih i jedna staleška sekcija (Sekcija opštinskih lekara za Beograd, Zemun i Pančevo, 1931). Posle Drugog svetskog rata, sledeći opšti entuzijazam koji je tada postojao u društvu, izazvan potrebom obnove i izgradnje svih segmenata života u socijalističkoj Jugoslaviji, u okviru Srpskog lekarskog društva osnivaju se podružnice i sekcije. Kao 16. po redu, 1950. godine, osniva se Sekcija za istoriju medicine i farmacije (od 1980. Sekcija za istoriju medicine). Prvi sastanak Sekcije održan je 29. marta 1950. Za predsednika Sekcije izabran je sanitetski general prof. dr Vladimir Stanojević. Prvo predavanje koje je održao profesor Aleksandar Đ. Kostić (Jedan stogodišnji srpski leksikon), takođe je ukratko prikazano u radu. Tokom 70 godina trajanja, Sekcija je imala uspone i padove, formalni kontinuitet je postojao, međutim aktivnost je bila neujednačena (redovnost održavanja sastanaka, broj iznetih saopštenja i sl), tako da se njen rad može podeliti na četiri perioda. Sekcija je najbolje rezultate rada beležila u prvom (1950-1978) i četvrtom periodu (2009-2020). Drugi period (1978-1993) karakteriše opadanje aktivnosti, a treći (1993-2009) potpuna pasivnost. Sekcija je u prvom i četvrtom periodu imala bogatu izdavačku delatnost. Dva puta je proglašena za najbolju sekciju Srpskog lekarskog društva - 2016. i 2017. godine.

Ključne reči: sekcije Srpskog lekarskog društva, istorija medicine

\begin{abstract}
This paper covers the forming of the Serbian Medical Society sections in the period until 1950, as well as the amendments made to the Rules of the Serbian Medical Society in 1919 and 1928. Prior to World War I, the Section for Tuberculosis was formed (1907). In the interwar period, seven specialist sections and one class section (Section of District Doctors for Belgrade, Zemun and Pančevo, 1931) were formed. After World War II, led by the all-pervasive enthusiasm in society of that time and the need for renewing and rebuilding all life segments in socialist Yugoslavia, new sections and regional branches of the Serbian Medical Society were established. The Section for the History of Medicine and Pharmacy was founded as the $16^{\text {th }}$ section of the Serbian Medical Society, in 1950, and, in 1980, its name was changed to - Section for the History of Medicine. The first meeting of the Section was held on March 29, 1950. Professor Vladimir Stanojević, PhD, Medical Corps General, was elected the first President of the Section. The first lecture, delivered by Professor Aleksandar Đ. Kostić (Jedan stogodišnji srpski leksikon)', is also described briefly in this paper. During its 70 years of work, the Section has experienced periods of rise and fall in its activity; while there has been formal continuity in its work, activity has been irregular (the regularity of the meetings, the number of communications, etc.), which is why its history can be divided into four periods. The Section achieved its best results in the first (1950-1978) and in its fourth (2009-2020) period. The second period (1978-1993) was characterized by a decrease in activity, while the third (1993-2009) was a period of complete inactivity. The Section had a fruitful publishing activity during the first and the fourth period. It was voted the best section of the Serbian Medical society twice - in 2016 and 2017.
\end{abstract}

Key words: sections of the Serbian Medical Society, history of medicine

1 Translator's note: Title translation - A One-hundred-year-old Serbian Lexicon
Autor za korespondenciju:

Zoran Vacić

Akademija medicinskih nauka Srpskog lekarskog društva

Džordža Vašingtona 19, 11100 Beograd, Srbija

Elektronska adresa: jeremija1955@gmail.com

\author{
Corresponding author: \\ Zoran Vacić \\ Academy of Medical Sciences of the Serbian Medical Society \\ 19 Džordža Vašingtona Street, 11100 Belgrade, Serbia \\ E-mail:jeremija1955@gmail.com
}

Prihvaćen • Accepted: November 21, 2020; Online first: December 25, 2020.

Primljen • Received: November 6, 2020; Revidiran • Revised: November 13,2020; Prihvaćen •
DOI: 10.5937/SMCLK2002149V 


\section{UVOD}

Od osnivanja 1872. godine, pa do okončanja Prvog svetskog rata (1919), Srpsko lekarsko društvo (SLD) je stručne i naučne sastanke držalo u plenumu. Ako se izuzme ad hoc osnovana "naročita Sekcija za tuberkulozu pri Srpskom lekarskom društvu" čiji su članovi bili doktori M. P. Jevremović, Lj. Stojanović i M. Ivković [1], specijalističkih sekcija sve do 1922 . godine u sastavu SLD nije bilo. Te godine, lekari Vrnjačke Banje osnovali su Balneološku sekciju SLD [2].

Zašto pre Velikog rata nisu osnivane specijalističke sekcije u okviru SLD? Prvi razlog bi bio malobrojnost specijalista pojedinih grana medicine. Članovi SLD bili su doktori medicine, odnosno doktori celokupnog lekarstva, koji su se uglavnom bavili „opštom praksom”, ali i posebnim granama medicine, iako nisu bili specijalisti. Lekari koji su radili u Opštoj državnoj bolnici ili Duševnoj bolnici usmeravali su se ka pojedinim specijalističkim granama medicine, ali je broj onih koji su po okončanju studija završavali i specijalizaciju na nekom od evropskih medicinskih fakulteta bio mali. Drugi razlog je strah da će se osnivanjem sekcija "razdrobiti" struktura SLD. I u međuratnom periodu, u diskusijama vođenim na redovnim godišnjim skupštinama SLD, provejavala je bojazan da će se osnivanjem većeg broja sekcija naučni rad izmestiti iz Društva i da će ono prestati da postoji. Na 50. godišnjoj skupštini, održanoj 1928. godine, dr Zdravković govori o potrebi da se "donese pravilnik za sekcije koje postoje. Obrazovane su sekcije, za dečju medicinu, za venerologiju i ako se obrazuju za sve grane medicine, onda šta je ostalo SLD, čime će ono da se bavi?". Dr Svetislav Stefanović je podržao stav dr Zdravkovića i dodao da bi tim pravilnikom trebalo da se „propiše, da se sekcije vežu za maticu, a ne da se odvoje i idu na štetu Društva" [3].

Pravni osnov za osnivanje sekcija predstavljale su izmene Pravila $S L D^{1}$ usvojene na 41. glavnom godišnjem skupu SLD, održanom 22. novembra 1919. godine. Dr Vojislav J. Subbotić je predložio, zajedno sa još 23 člana SLD (među njima su bili i Jovan Danić, Lazar Genčić, Roman Sondermajer, Leon Kojen, Vojislav M. Subotić, Dušan Stojimirović), da se Pravilima SLD omogući osnivanje stručnih sekcija na predlog najmanje 10 članova SLD. Osnivanje sekcija obrazloženo je potrebom da se pristupi „diferenciranju stručnih radova i udubljenju radova i diskusija" [4].

Zašto se na prvom posleratnom Glavnom godišnjem skupu daju predlozi za radikalnu izmenu Pravila $S L D$ ?

Zastupnik ministra narodnog zdravlja, ministar za socijalnu politiku Vitomir Korać potpisao je 29. oktobra

\footnotetext{
Statut Srpskog lekarskog društva
}

\section{INTRODUCTION}

Since its founding, in 1872, until the end of World War I, in 1919, the Serbian Medical Society (SMS) held its professional and scientific meetings as plenary sessions. With the exception of a "special Section for Tuberculosis of the Serbian Medical Society" formed ad hoc, whose members were doctors M. P. Jevremović, Lj. Stojanović, and M. Ivković [1], there were no specialist sections within the SMS until 1922. That year, the doctors from Vrnjačka Banja founded the Section for Balneology of the SMS [2].

Why were no specialist sections established within the SMS before the Great War? The first reason was the fact that there were few specialists of individual medical fields at the time. The members of the SMS were doctors of overall medicine, who were mainly in general practice, but they also practiced other specific branches of medicine, even though they were not specialists in those particular fields. Doctors working at the General State Hospital or the Mental Hospital would direct their focus at a certain specialist branch of medicine, but the number of those who, after graduation from medical school, actually specialized at any of the European medical schools, was small. The second reason was the fear that the founding of sections would "fragment" the structure of the SMS. Even in the interwar period, discussions at regular annual assemblies continued to be pervaded by the fear that the forming of a larger number of sections would remove the scientific work away from the SMS itself, and that it would cease to exist. At the $50^{\text {th }}$ Annual General Assembly, held in 1928, Dr. Zdravković spoke of the need for "adopting a rulebook for the existing sections". Sections for pediatrics, venerology have been formed, and if sections are formed for each branch of medicine, what remains then for the SMS, what will its purpose and scope of work be?". Dr. Svetislav Stefanović supported the view expressed by Dr. Zdravković and added that the rulebook should "prescribe the affiliation and bond of the sections to the SMS and prevent their secession, to the detriment of the Society" [3].

The legal framework for establishing the sections was founded in the amendments to the Rules of the SMS', which were adopted at the $41^{\text {st }}$ Annual General Assembly, held on November 22, 1919. Dr. Vojislav J. Subbotić, together with 23 other members of the je SMS (amongst them Jovan Danić, Lazar Genčić, Roman Sondermajer, Leon Kojen, Vojislav M. Subotić, Dušan Stojimirović) proposed that the Rules of the SMS be amended so as to allow the approval of proposals for founding specialist sections, with the proviso that at least 10 members of

\footnotetext{
2 Statute of the Serbian Medical Society
} 
1919. godine Uredbu olekarima specijalistima [5]. Ovom Uredbom, koja će, u maltene istovetnom tekstu, postati Zakon o lekarima specijalistima [6], propisani su uslovi za dobijanje naziva specijaliste i 16 specijalističkih grana medicine ${ }^{2}$. Zahvaljujući ovoj Uredbi, veći broj članova SLD mogao je da ponese naziv specijaliste, što je moglo da omogući i formiranje sekcija. Jedan od razloga za stvaranje sekcija je temeljniji pristup u prezentaciji dijagnostike i terapije pojedinih oboljenja, pa su članovi specijalističkih sekcija mogli da šire krug svog znanja i da se neposredno (ili posredno) upoznaju sa dostignućima evropske medicine. U izveštaju Upravnog odbora o radu SLD, podnetom na 43. glavnom godišnjem skupu piše „Upravni Odbor stojeći na stanovištu, da je Srpsko lekarsko društvo, i pored novog osnovanog medicinskog fakulteta, a naročito do mogućnosti njegove pune akcije, pozvano da brine o kultiviranju i razvijanju medicinske discipline, uložio je svu svoju pažnju, da u naučnom pogledu koraknemo napred". Takođe, i da će izgradnja Doma Srpskog lekarskog društva omogućiti „realiziranje društvene biblioteke... obrazovanje stručne sekcije" [7]. U Srpskom lekarskom društvu snažno je živela ideja Očeva osnivača SLD, da Društvo treba "da prati svojim radom suvremeno razvijanje medicinske nauke i onih grana jestastvenice koje su joj pomoćnice; da napreduje sa postepenim razvitkom lekarstva, da se usavršava svagdanjim njegovim iskustvom, da rasprostire to iskustvo pismenim i usmenim saopštavanjima o svome i tuđem iskustvu..."3 [8].

U međuratnom periodu (1918-1941), posle Balneološke sekcije, osnivaju se Sekcija za tuberkulozu (1923) [9], Sekcija za dečiju medicinu (1925) [10], Dermatovenerološka (1928) [11], Radiološka (1929) [12], Ftiziološka (1931) [13] i Stomatološka sekcija (1933) [14].

Na 50. godišnjoj skupštini SLD (1928), statutarnim izmenama omogućeno je osnivanje "staleških" sekcija koje za cilj imaju poboljšanje materijalnog statusa lekara [15]. Sekcija opštinskih lekara za Beograd, Zemun i Pančevo osniva se 1931. godine [16].

Posle Drugog svetskog rata, u okviru Srpskog lekarskog društva dolazi do osnivanja ili obnove rada većeg broja sekcija. Najpre, 1946. godine, počinju sa radom Sekcija za fiskulturnu (sportsku) medicinu, Radiološka

\footnotetext{
Zvanje specijaliste mogli su dobiti nastavnici medicinskih fakulteta, potom klinički asistenti i lekari koji su službovali u „svojoj struci” u građanskim ili vojnim bolnicama (u Beogradu, Zagrebu, Ljubljani i Sarajevu) najmanje dve godine, lekari koji su se u,svojoj struci naročito odlikovali" na osnovu mišljenja Sanitetskog saveta, i šefovi odeljenja u bolnicama sa "više od dva odeljenja”. (čl. 1 Uredbe o lekarima specijalistima)

3 Ocelji društvenoj, čl. 1

4 Ftiziološka sekcija SLD je nastala spajanjem Sekcije za tuberkulozu SLD i Ftiziološkog društva Beograda.
}

the SMS should second such a proposal. The establishing of new sections was justified by the need to "differentiate professional papers and deepen the discussions and provide greater depth of the papers" [4].

Why were proposals for a radical change in the Rules of the SMS made at the first Annual General Assembly held after World War I?

On October 29, 1919, the representative of the Minister of National Health, the Minister of Social Affairs Vitomir Korać signed the Ordinance on Medical Specialists [5]. This Ordinance, which would, in practically the same form, become the Law on Medical Specialists [6], prescribed the conditions for receiving the title of specialist, as well as the 16 specialty branches of medicine. ${ }^{3}$ Thanks to this Ordinance, a significant number of SMS members could obtain the title of specialist, which made the establishing of SMS sections possible. One of the reasons for forming sections was a more thorough approach in the presentation of the diagnostics and therapy for individual diseases, which made it possible for members of the specialist sections to broaden their knowledge and to directly, or indirectly, learn about the achievements in European medicine. The report of the Governing Board on the work of the SMS, submitted at the $43^{\text {rd }}$ Annual General Assembly, states: "On the basis of the position of the Governing Board that the Serbian Medical Society, regardless of the newly founded Faculty of Medicine, and especially until the full activity of the Faculty is established, remains called upon to cultivate and develop medicine as a science, the Serbian Medical Society has invested all its effort to achieve steps forward in the domain of science". The report also states that the building of the House of the Serbian Medical Society would enable the "formation of a library... the founding of specialist sections" [7]. The ideas of the Founding Fathers of the Serbian Medical Society were very much alive within the Society; these being that the SMS "should follow with its work the modern development of medicine and all the branches of natural science associated with it; should develop with the gradual development of medical practice and advance through its everyday experience; should disseminate this experience through written and oral communications regarding its own and the experience of others ..." ${ }^{4}$ [8].

\footnotetext{
The title of specialist could be obtained by the lecturers at the Faculty of Medicine, clinical assistants and doctors working in "their field", in civilian and army hospitals (in Belgrade, Zagreb, Ljubljana and Sarajevo) for a period of at least two years, doctors who "had particular achievements in their fields", according to the opinion of the Medical Council, and heads of hospital wards in hospitals which had "more than two wards" (Article 1 of the Ordinance on Medical Specialists).

4 O celji društvenoj (The Social Aim), Article 1
} 
i Kardiološka sekcija; naredne godine biće osnovane Sekcija za higijenu, Neuropsihijatrijska sekcija, Sekcija lekara socijalnog osiguranja, a do 1950. godine, biće osnovane ili će obnoviti rad sledeće sekcije: Ginekološko-akušerska, Dermatovenerološka, Otorinolaringološka, Oftalmološka, Sekcija za medicinsku hidrologiju i klimatologiju, Pedijatrijska, Reumatološka, Stomatološka i Ftiziološka sekcija [17]

\section{OSNIVANJE SEKCIJE ZA ISTORIJU MEDICINE I FARMACIJE}

Istorija medicine je naučna oblast koja se u Srbiji istražuje više od sto pedeset godina. Istraživanja su, do osnivanja Sekcije za istoriju medicine i farmacije SLD, bila sporadična. Osnivanjem Sekcije započinje period institucionalizovanog izučavanja istorije srpske medicine koji će dovesti do osnivanja drugih organizacija sa istim ciljevima: Sekcije za istoriju medicine, veterine i farmacije pri Institutu za medicinska istraživanja SANU (1955) i Jugoslovenskog društva za istoriju medicine, farmacije i veterinarstva (1955) [18].

Podnoseći izveštaj o radu na Jugoslovenskoj medicinskoj bibliografiji, na sastanku Srpskog lekarskog društva održanom 9. decembra 1949. godine, dr Zdenko Levental je predložio da SLD formira Sekciju za istoriju medicine koja bi "najviše doprinela” da se rad na medicinskoj bibliografiji što pre okonča. Predlog je sa oduševljenjem pozdravio prof. dr Kosta Todorović, potom i drugi učesnici sastanka [19].

Sekcija za istoriju medicine i farmacije osnovana je 12. februara 1950. godine, kao 16. po redu sekcija SLD. Sanitetski general, profesor Vladimir Stanojević izabran je za predsednika, dr Aleksandar Šević iz Čačka za potpredsednika, a Zdenko Levental za sekretara. Članovi Uprave bili su dr Milorad Dragić i mr farm. Vojislav Marjanović. Za počasnog predsednika „izabran je nestor naših mediko-istoričara dr Risto Jeremić". Prvi sastanak Sekcije održan je 29. marta 1950. Saopštenja su imali profesor Aleksandar Kostić (Jedan stogodišnji srpski leksikon) i dr Milorad Dragić (Mađiski elementi kao faktor u genezi higijene) [20].

Osnivači su odredili zadatke Sekcije: (1) prikupljanje svih dosadašnjih podataka iz naše zdravstvene književnosti i izrada bibliografije srpske zdravstvene književnosti u prošlosti i sadašnjosti; (2) obrada otkrivene građe i pronalaženje nove građe za istoriju medicine i farmacije; (3) stvaranje naučnog podmlatka i buđenje interesa za istoriju medicine u široj medicinskoj javnosti; (4) uspostavljanje saradnje sa naučnicima iz svih oblasti koje se graniče sa istorijom medicine i

Od 1980. godine zvanični naziv je - Sekcija za istoriju medicine Srpskog Lekarskog Društva.
In the period between World War I and World War II (1918-1941), after the Section for Balneology, the Section for Tuberculosis (1923) [9], the Section for Children's Medicine (1925) [10], the Section for Dermatovenerology (1928) [11], the Section for Radiology (1929) [12], the Section for Phthisiology $(1931)^{5}$ [13] and the Section for Stomatology (1933) [14] were also formed.

At the $50^{\text {th }}$ Annual General Assembly of the SMS (1928), the establishing of "class" sections was made possible by amendments to the Statue, with the aim of improving the financial status of doctors [15]. The Section of District Doctors of Belgrade, Zemun and Pančevo was established in 1931 [16].

After World War II, numerous sections of the Serbian Medical Society were either formed or restored to activity. First, in 1946, the Section for Physical Education (Sports) Medicine started with its activity, as well as the Section for Radiology and the Section for Cardiology. The following year, the Section for Hygiene, the Section for Neuropsychiatry, the Section of the Doctors of Social Insurance were also formed, and, by 1950, the following sections were either established or renewed their activity: the Section for Gynecology and Obstetrics, the Section for Dermatovenerology, the Section for Otorhinolaryngology, the Section for Ophthalmology, the Section for Medical Hydrology and Climatology, the Section for Pediatrics, the Section for Rheumatology, the Section for Stomatology, and the Section for Physiology [17] .

\section{FOUNDING OF THE SECTION FOR THE HISTORY OF MEDICINE AND PHARMACY}

The history of medicine is an area of science which has been studied in Serbia for more than 150 years. Research in this area, before the founding of the Section for the History of Medicine and Pharmacy of the SMS ${ }^{6}$, was sporadic. The founding of the Section marked the beginning of institutionalized study of the history of Serbian medicine, which would lead to the establishing of other organizations with the same goals: the Section for the History of Medicine, Veterinary Medicine and Pharmacy of the Institute for Medical Research at the Serbian Academy of Sciences and Arts (1955), and the Yugoslav Society for the History of Medicine, Pharmacy and Veterinary Medicine (1955) [18].

Reporting on the work on the Yugoslav Medical Bibliography, at the meeting of the Serbian Medical Society held on December 9, 1949, Dr. Zdenko Levental proposed that the SMS should form a Section for

\footnotetext{
5 The Section for Phthisiology of the Serbian Medical Society was formed by the merging of the Section for Tuberculosis of the SMS and the Belgrade Phtisiology Society.

6 As of 1980, the official name is - Section for the History of Medicine of the Serbian Medical Society.
} 
farmacije; (5) stvaranje Katedre za istoriju medicine na Medicinskom fakultetu u Beogradu; i (6) osnivanje Muzeja Srpskog lekarskog društva [21].

\section{SAOPŠTENJE PROF. DR ALEKSANDRA Đ. KOSTIĆA}

Poziv Predsedništva Sekcije za istoriju medicine i farmacije upućen profesoru Aleksandru Đ. Kostiću da predavanjem o delu našeg prvog socijalnog medicinara, dr Konstantina Peičića, otvori seriju stručnih sastanaka, proistekao je iz ciljeva Sekcije - da prikuplja i analizira podatke "iz naše zdravstvene književnosti". Takođe, u vremenu kada je došlo do naglašene socijalizacije medicine, ovim predavanjem je ukazano da su ideje socijalizovane medicine duže od jednog veka prisutne među srpskim lekarima. Kostićev, pak, izbor da prikaže delo Rukovoditelj k' povraćanju izgubljenog zdravlja odraziće njegova lična interesovanja: bibliofiliju i rad na medicinskoj terminologiji. Uostalom i sam naziv rada O jednom stogodišnjem srpskom medicinskom leksikonu [22] ukazuje na Kostićeva leksikografska i terminološka istraživanja.

Konstantin Peičić (Borovo, 1802 - Budimpešta, 1882) je medicinu studirao i završio u Pešti. Promovisan je u doktora medicine 1830 . godine sa raspravom Dissertatio inauguralis medicopolitica de pauperum aegrorum cura (Zdravstvena politika lečenja bolesne sirotinje). Peičić je svoju disertaciju, koja je naš prvi socijalno-medicinski rad, objavio iste godine u Budimu na srpskom jeziku. Peičić, „poslednji Dositejev učenik” [23], objaviće, nadahnut prosvetiteljskim idejama svog učitelja, pored disertacije, knjige Rukovoditelj k sveopštem zdravlju (Budim, 1830), Rukovoditelj k' izgubljenom zdravlju (Budim, 1934) i Rukovoditelj k' povraćanju izgubljenog zdravlja (Novi Sad, 1840) [24]. Zajedno sa dr Ljubomirom Nenadovićem uređivao je prvi popularni medicinski časopis objavljivan na srpskom jeziku - Domaći lekar (1871-1873).

Peičić knjigu Rukovoditelj k' povraćanju izgubljenog zdravlja započinje pravilima za očuvanje telesnog zdravlja, posebno ističući psiho-fizičko jedinstvo čoveka. Govoreći o čuvanju zdravlja, zagovara mnoga, i danas važeća, higijenska i dijetetska pravila. Posebno ukazuje da je nepravilna ishrana (nedovoljna upotreba povrća, rđav način pripreme hrane) uzrok mnogih bolesti. Potom slede opšta izlaganja o bolestima. U sledećem odeljku, o lečenju i lekovima, Peičić se zalaže za upotrebu lekovitog bilja („,mnogi nam lekovi u našoj zemlji po livadama, šumama itd. rastu") opisujući način spremanja lekova (čajevi, dekokti, praškovi). Specijalnu pažnju, u skladu sa tadašnjim medicinskim shvatanjima, posvećuje puštanju krvi kao terapijskoj metodi, uz detaljna uputstva za korišćenje pijavica. Peičić piše i o the History of Medicine which would "contribute the most" to the faster completion of the work on the medical bibliography. This suggestion was seconded with great enthusiasm by Dr. Kosta Todorović, and after that by other members at the meeting [19].

The Section for the History of Medicine and Pharmacy was formed on February 12,1950 , as the $16^{\text {th }}$ section of the SMS. Medical Corps General, Professor Vladimir Stanojević was elected President, Dr. Aleksandar Šević from Čačak was elected Vice-President, and Dr. Zdenko Levental was appointed Secretary of the Section. The members of the Governing Body were Dr. Milorad Dragić and Vojislav Marjanović, MPharm. "Dr. Risto Jeremić, the sage of our medical historians" was appointed Honorary President. The first meeting of the Section was held on March 29, 1950. Communications were delivered by Professor Aleksandar Kostić (Jedan stogodišnji srpski leksikon) and Dr. Milorad Dragić (Mađiski elementi kao faktor u genezi higijene) ${ }^{7}$ [20].

The founders defined the objectives of the Section: (1) collecting all data from our medical literature to date, and writing a bibliography of Serbian medical literature, past and present; (2) processing known sources and literature and discovering new sources and literature relevant to the history of medicine and pharmacy; (3) cultivating a younger generation of medical historians by raising interest in this area within the wider medical public; (4) cultivating cooperation with scientists from all areas relevant to the history of medicine and pharmacy; (5) founding the Department of the History of Medicine at the faculty of Medicine in Belgrade; and (6) founding the Museum of the Serbian Medical Society [21].

\section{PROF. DR ALEKSANDAR Đ. KOSTIĆ'S COMMUNICATION}

The invitation of the Governing Body of the Section for the History of Medicine and Pharmacy extended to Professor Aleksandar Đ. Kostić to open the series of professional meetings with a lecture on the work of the first doctor to promote social medicine in our country, Dr. Konstantin Peičić, was motivated by the objective of the Section to collect and analyze data and information "from our medical literature". Also, at a time when there was a strong emphasis on the socialization of medicine, this lecture showed that the ideas of socialized medicine were present amongst Serbian doctors for over a century. Professor Kostić's choice to present the book Rukovoditelj k' povraćanju izgubljenog zdravlja ${ }^{8}$, on the other hand, was an expression of the professor's personal interests - bibliophilia and work

Translator's note: Title translation - Elements of Magic as Factors in the Genesis of Hygiene

8 Translator's note: Title translation - The Guidebook to Recovering Lost Health 
upotrebi hladne i tople lekovite vode u lečenju pojedinih bolesti. U skladu sa tada aktuelnom klasifikacijom, oboljenja deli na "spoljašnja" i "unutrašnja”. U nervne bolesti svrstava konvulzije, glavobolju, nesanicu, nesvesticu, paralizu, epilepsiju i besnilo. Njegovi stavovi su zasnovani na tetrahumoralnoj teoriji o nastanku bolesti; primera radi, melanholiju naziva crnožučije („церножучіе") ${ }^{6}$. Knjigu završava izlaganjem pravila prve pomoći pri nesrećnim slučajevima.

$\mathrm{U}$ analizi ovog dela profesor Kostić daje iscrpne komentare sa aspekta moderne medicine. Tako, na primer, piše da je čudno da Peičić u odeljku o bolestima grla i prsiju ne „obraća veću pažnju na tuberkulozu, koju on naziva 'эктика кашальна". Iskašljavanje krvi ne dovodi u vezu s tuberkulozom". Ukazuje i da Peičić "pege" na licu opisuje zajedno sa zaraznim osipnim bolestima (kravlje boginje, male boginje, crveni vetar, itd.), mada zna za prenosivost boginja.

Aleksandar Đ. Kostić je ovim radom dao dvostruki doprinos istoriji srpske medicine. Prvi, knjigu koja predstavlja bibliofilski raritet $^{8}$, temeljno prikazuje, analizirajući sve aspekte Peičićevog dela, čime širu publiku upoznaje sa ovim značajnim delom naše medicinske književnosti. Drugi, mnoge izraze pisane predvukovskom recenzijom "prevodi" u modernu medicinsku i botaničku terminologiju, dajući pri tom i narodne nazive.

Po Kostićevom predavanju videlo se da je Sekcija krenula dobrim putem.

\section{RAD SEKCIJE ZA ISTORIJU MEDICINE (1950-2020)}

Tokom sedamdeset godina svog postojanja, Sekcija je beležila uspone i padove, formalni kontinuitet je postojao, međutim bila je prisutna neujednačena aktivnost (redovnost održavanja sastanaka, broj iznetih saopštenja i sl.), tako da se njen rad može podeliti na četiri perioda:

Prvi period izuzetno plodnog rada trajao je od osnivanja 1950. do 1978. godine, tj. do smrti prvog predsednika - profesora Vladimira Stanojevića. Održano je 257 sastanaka na kojima su 124 autora saopštila 522 rada. Osnovan je i Muzej srpske medicine SLD (1955). Članovi Sekcije su učestvovali na lekarskim kongresima i naučnim skupovima koje su organizovali Jugoslovensko društvo za istoriju medicine, farmacije

6 Hipokratska škola uči da postoje četiri životna soka-humora u telu (krv, sluz / flegma, žuta žuč i crna žuč). Svaki od humora povezan je sa jednim od četiri temperamenta. Crnaoj žuči odgovara melanholik.

Jektika s kašljem - primedba Z. V.

8 Kostić je za analizu koristio primerak iz svoje biblioteke „Na mome primerku II izdanja ovog leksikona stoji napisano..." on medical terminology. The very title of the paper $O$ jednom stogodišnjem srpskom medicinskom leksikonu ${ }^{9}$ [22] is a clear testimony of the professor's research in lexicography and terminology.

Konstantin Peičić (Borovo, 1802 - Budapest, 1882) completed his medical studies in Pest. He was promoted to Doctor of Medicine in 1830, with his dissertation Dissertatio inauguralis medicopolitica de pauperum aegrorum cura (The Health Policy of Treating the Poor). That same year, in Buda, Peičić published his dissertation, in the Serbian language; this was the first Serbian paper in social medicine. Inspired by the Enlightenment ideas of his teacher, Peičić, "the last of the scholars of Dositej"10 [23], would go on to publish, in addition to his dissertation, the books-Rukovoditeljksveopštem zdravlju"1 (Buda, 1830), Rukovoditelj k' izgubljenom zdravlju'12 (Buda, 1934) and Rukovoditelj k' povraćanju izgubljenog zdravlja (Novi Sad, 1840) [24]. Together with Dr. Ljubomir Nenadović, he edited the first popular medical journal published in the Serbian language, Domaći lekar ${ }^{13}$ (1871-1873).

Peičić begins the book Rukovoditelj k' povraćanju izgubljenog zdravlja with rules for preserving bodily health, with special emphasis on the psychophysical unity of man. When speaking of preserving health, he advocates many rules of hygiene and diet that are still valid to this day. He especially points out that poor diet (lack of vegetables in the diet or improper preparation of food) is the cause of many illnesses. He then goes on to provide general descriptions of diseases. In the next section, on treatment and drugs, Peičić advocates the use of herbs ("many a medicine in our country grows on meadows or in forests, etc.") and describes the methods of their preparation (tea, decoctions, powders). He gives special attention, in keeping with the ideas of medicine at the time, to bloodletting as a therapeutic method, with detailed instructions on the use of leeches. Peičić also writes on the use of cold and warm therapeutic water in treating certain diseases. In keeping with the then generally accepted classification, he divides diseases into "external" and "internal" illnesses. He classifies convulsions, headache, insomnia, fainting, paralysis, epilepsy and rabies as nervous diseases. His beliefs are based on the humoral theory of the origin of diseases; for instance, he calls melancholy

\footnotetext{
9 Translator's note: Title translation - On a One-hundred-year-old Serbian Medical Lexicon

10 Translator's note - One of the most prominent Serbian scholars and proponents of Enlightenment

11 Translator's note: Title translation - The Guidebook to Overall Health

12 Translator's note: Title translation - The Guidebook for Lost Health

13 Translator's note: Title translation - Home Doctor
} 
i veterinarstva, odnosno Naučno društvo za istoriju zdravstvene kulture Jugoslavije ${ }^{9}$ i lekarska udruženja iz drugih republika tadašnje Jugoslavije. Velika pažnja posvećivana je jubilarnim godišnjicama značajnih medicinskih ustanova, SLD, lekara (dr-a Laze K. Lazarevića, Petra Miljanića, Jovana Jovanovića Zmaja i drugih) $i$ istaknutih ličnosti naše naučne i kulturne istorije, poput Branka Radičevića, Petra Petrovića Njegoša ili dr Jovana Cvijića. Među osnivačima i članovima Sekcije nalazio se i veliki broj učesnika Velikog rata, pa su se na sastancima mogla čuti autentična svedočanstva savremenika o prelasku srpske vojske preko Albanije; radu saniteta na Krfu i Solunskom frontu; ulozi saniteta pri proboju Solunskog fronta; o britanskim i drugim stranim sanitetskim misijama. Objavljeno je i osam knjiga Zbornika radova saopštenih na sastancima Sekcije (Slika 1).

U drugom periodu (1978 - 1993) rad Sekcije gubi na intenzitetu. Posle smrti profesora Stanojevića za predsednika Sekcije izabran je mr farmacije dr Vojislav Marjanović. U periodu njegovog rukovođenja sekcijom "nastupio je izvestan zastoj u radu" koji je trajao do marta 1980. kada za predsednika biva izabran primarijus Milorad Dragić, koji je dužnost obavljao do 1983. godine.

Sekcija je 1980. godine promenila ime u Sekcija za istoriju medicine. Održana su 22 sastanka na kojima su saopštena 34 rada. Od 1983. do 1993. predsednik Sekcije bio je dr Krsta Živković. Ovaj period karakteriše neredovno održavanje sastanaka, organizovanih najčešće prigodom obeležavanja pojedinih jubileja. Potpisan je "pismeni dogovor" sa Naučnim društvom za istoriju zdravstvene kulture Srbije, kojim je predviđeno održavanje zajedničkih sastanaka. Kako stoji u izveštaju od 17. decembra 1986. godine, koji su potpisali dr Krsta Živković, predsednik Sekcije, i dr Budimir Pavlović, sekretar, „,ovime su ostvareni u pismenoj formi, raniji započeti dobri odnosi i saradnja između ova dva skupa, u interesu, zajedničkog rada na proučavanju i popularizaciji istorije srpske medicine i zdravstvene kulture." [25]. Izbijanjem građanskog rata na prostorima SFRJ, Naučno društvo za istoriju zdravstvene kulture Jugoslavije prestaje da postoji, a ubrzo i Naučno društvo za istoriju zdravstvene kulture Srbije prestaje sa radom.

Treći period, od 1993. do 2009. godine je period potpune neaktivnosti Sekcije na čijem se čelu nalazio dr Budimir Pavlović. Budući da Sekcija godinama nije dostavljala izveštaje o radu i nije imala aktivne članove, Predsedništvo SLD je 24. septembra 2004. godine

9 Jugoslovensko društvo za istoriju medicine, farmacije i veterinarstva osnovano 27. oktobra 1955. godine, 15. decembra 1962. godine menja ime u Naučno društvo za istoriju zdravstvene kulture Jugoslavije. черножучіе $e^{14}$ - black bile illness. He finishes the book with instructions on first aid in case of accidents.

In his analysis of this book, Professor Kostić provides detailed comments from the aspect of modern medicine. Thus, for instance, he comments that it is peculiar how, in the section on diseases of the throat and chest, Peičić "does not give more attention to tuberculosis, which he calls 'эктика кашальна'15. He does not make a connection between coughing up blood and tuberculosis." Kostić also points out that Peičić describes "spots" on the face together with infectious diseases characterized by rash (cowpox, St. Anthony's fire, etc.) although he is aware that pox is contagious.

With this paper, Aleksandar $Đ$. Kostić contributed to the history of medicine in a twofold manner. Firstly, he presents the book itself, a bibliophilic rarity ${ }^{16}$, in great detail and in depth, analyzing all aspects of Peičić's work, thereby introducing this important title of Serbian medical literature to the broader public. Secondly, he translates many archaic terms into modern botanical and medical terminology, at the same time providing layman's terms for them, as well.

The lecture delivered by Professor Kostić was an indicator tht the Section was on a good path.

\section{THE WORK OF THE SECTION FOR THE HISTORY OF MEDICINE (1950-2020)}

During its 70 years of work, the Section has experienced periods of rise and fall in activity; while there has been formal continuity in its work, activity has been irregular (the regularity of the meetings, the number of communications, etc.), which is why its history can be divided into four periods.

The first period of very fruitful work lasted from 1950 to 1978 , i.e., until the death of the Section's first President, Professor Vladimir Stanojević. In this period, there were 257 meetings of the Section where 124 authors presented 522 papers. The Museum of Serbian Medicine of the SMS was founded in 1955. The members of the Section took part at medical congresses and science gatherings organized by the Yugoslav Society for the History of Medicine, Pharmacy and Veterinary Medicine, i.e., the Scientific Society for the History of the Health Culture in

14 The Hippocratic school teaches that there are four life humors in the body (blood, phlegm, yellow bile, and black bile). Each one of the humors is connected to one of the four temperaments. The melancholy type is connected to black bile.

15 Author's note - Consumption with coughing

16 For the analysis, Kostić used a copy from his own library: "My copy of this book is a second edition of the lexicon, and it reads, as follows..." 


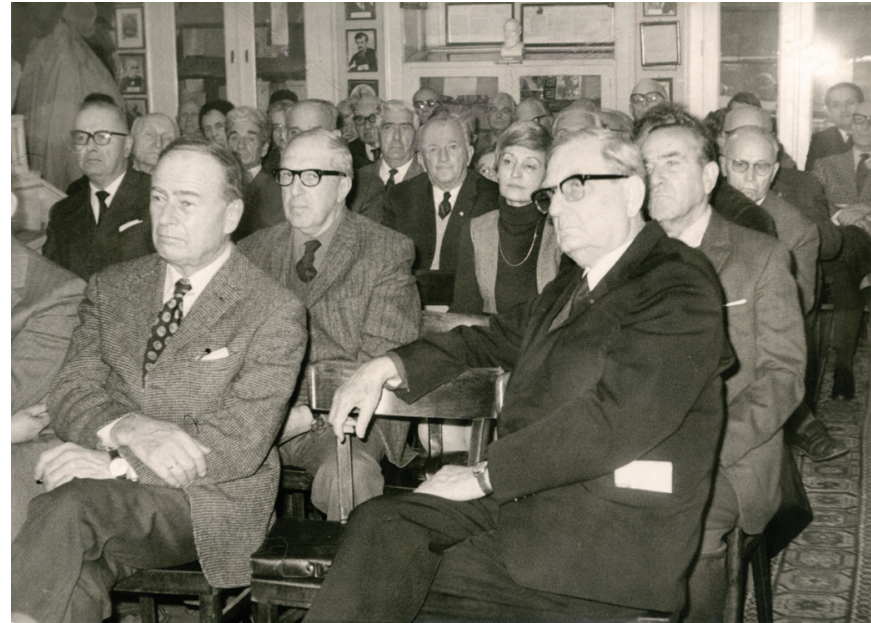

Slika 1. Sastanak Sekcije za istoriju medicine i farmacije SLD održan šezdesetih godina XX veka. (Izvor: Muzej nauke i tehnike - Zbirka Muzeja srpske medicine SLD)

Photo 1. Meeting of the Section for the History of Medicine and Pharmacy of the SMS, held in the 1960s. (Source: Museum of Science and Technology - Collection of the Museum of Serbian Medicine)

donelo odluku da se Sekcija ugasi ukoliko ne aktivira rad. lako i dalje nije radila, do gašenja Sekcije nije došlo.

Četvrti period rada Sekcije započeo je 2009. godine i traje do danas. Kao novoizabrani predsednik SLD (31. januara 2009.) profesor Radoje Čolović je doneo odluku da obnovi rad "zamrlih sekcija i podružnica”. O inicijativi da se obnovi Sekcija, profesor Brana Dimitrijević je u svojoj knjizi „Moja gerila” zapisao: „Krajem januara, početkom februara 2009. godine telefonski mi se javio prof. dr Radoje Čolović, dopisni član SANU. Reče da je postao predsednik Srpskog lekarskog društva, i da je voljan da obnovi rad zamrlih sekcija, među kojima je i Sekcija za istoriju medicine. Tražio je od pisca ovih redova da se prihvati dužnosti predsednika te sekcije i da okupi ljude." [26]. Na obnoviteljski sastanak Sekcije, održan 19. marta 2009. godine, pozvani su lekari za koje se znalo da se bave ili da žele da se bave istorijom medicine. Odziv je bio iznad svih očekivanja. Na sastanku je aklamacijom izabrano Predsedništvo Sekcije za čijeg je predsednika izabran profesor Brana Dimitrijević, i doneta odluka da se sastanci održavaju osam puta godišnje sa najmanje po dva saopštenja. Zatim je profesor Čolović održao predavanje pod naslovom Dr Aćim Medović - prvi predsednik Srpskog lekarskog društva (1872).

Profesor Dimitrijević bio je na čelu Sekcije do Treće izborne skupštine održane 6 . juna 2015. godine, kada je za predsednika Sekcije izabran dr Zoran Vacić, dotadašnji član Predsedništva, kome je na Četvrtoj izbornoj skupštini, održanoj u Novopazarskoj Banji, 7. juna 2019. godine, mandat produžen za još četiri godine (Slika 2).
Yugoslavia ${ }^{17}$ and other associations from other republics of the former Yugoslavia. Great attention was given to jubilees of important medical institutions, the SMS, and prominent doctors (Dr. Laza K. Lazarević, Dr. Petar Miljanić, Dr. Jovan Jovanović Zmaj, and others) as well as jubilees related to prominent individuals of the nation's scientific and cultural history, such as the poet Branko Radičević, the poet, philosopher and Prince-Bishop of Montenegro Petar Petrović Njegoš, or scientist Jovan Cvijić, PhD. Amongst the founders and members of the Section there were many veterans of the Great War, thus, authentic testimonies of the army's Great Retreat across Albania; the work of the Medical Corps on Corfu and the Salonika Front; the role of the Medical Corps in the Salonika Front breakthrough; and the work of British and other foreign medical missions, could be heard at the meetings of the Section. Eight Books of Proceedings, i.e., collections of papers presented at the Section meetings were published in this period (Photo 1).

In the second period (1978 - 1993), the work of the Section lost momentum. After the death of Professor Stanojević, Dr. Vojislav Marjanović, MPharm, was elected President of the Section. During the period of his leadership of the Section a "certain stagnation in the work occurred", which lasted until March 1980, when Primarius Milorad Dragić was elected President, which he remained until 1983.

In 1980, the Section changed its name to the Section for the History of Medicine. 22 meetings were held, and 34 papers were presented at these meetings. Between 1983 and 1993, the President was Dr. Krsta Živković. In this period the meetings were held irregularly, usually for the purpose of marking an anniversary or jubilee. A "written agreement" was signed with the Scientific Society for the History of Health Culture in Serbia, which stipulated the organization of joint meetings. As written in the report dated December 17, 1986, signed by Dr. Krsta Živković, Section President and Dr. Budimir Pavlović, Secretary, "therein previously initiated good relations and cooperation between the two societies are realized in written form, for the benefit of joint work on the study and public dissemination of the history of Serbian medicine and health culture." [25]. With the breakout of civil war in the territory of the former SFRY, the Scientific Society for the History of Health Culture in Yugoslavia ceased to exist, and soon after, the same happened with the Scientific Society for the History of Health Culture in Serbia.

The third period, from 1993 to 2009, was a time of complete cessation of the activity of the Section,

17 The Yugoslav Society for the History of Medicine, Pharmacy and Veterinary Medicine was founded on October 27, 1955, and on December 15, 1962, its name was changed to the Scientific Society for the History of Health Culture in Yugoslavia. 


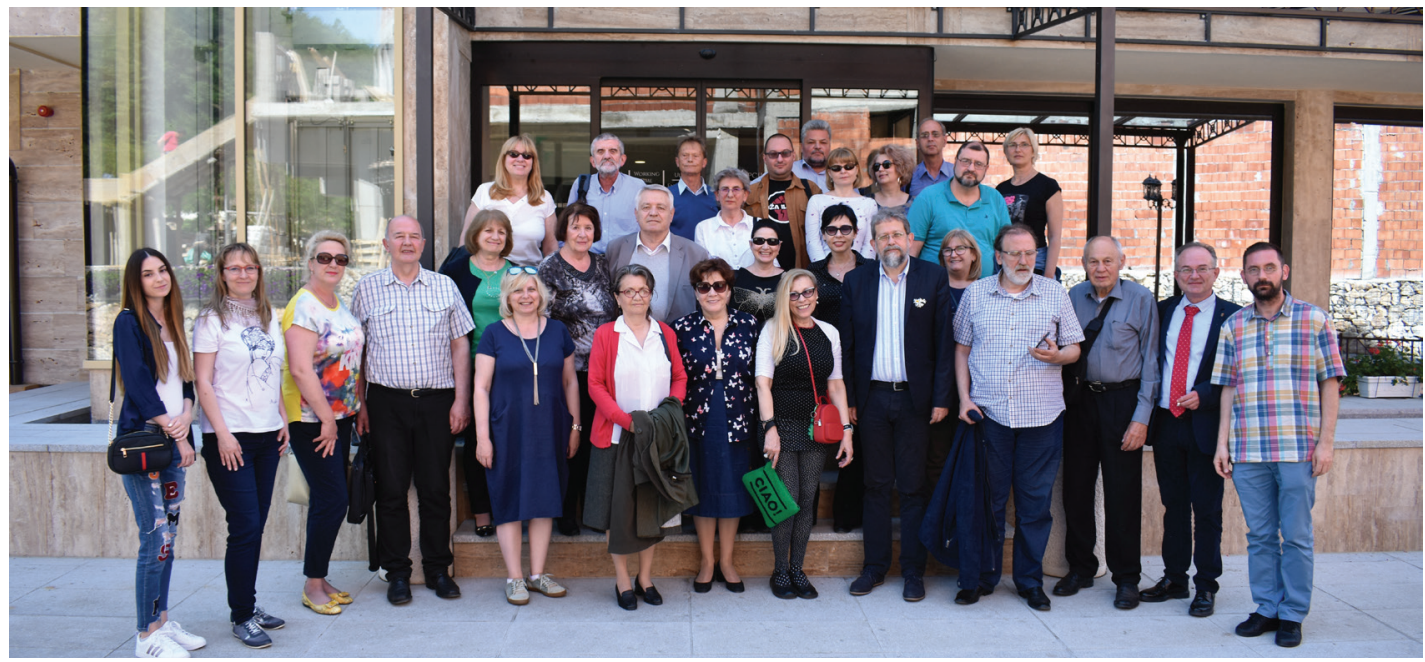

Slika 2. Učesnici 10. kongresa istoričara medicine (Novi Pazar, 7. jun 2019.). (Izvor: Arhiva Sekcije za istoriju medicine SLD)

Photo 2. Participants of the $10^{\text {th }}$ Congress of the Historians of Medicine (Novi Pazar, June 7, 2019). (Source: Archives of the Section for the History of Medicine of the SMS)

Počev od 2010. godine, Sekcija je organizovala redovne godišnje kongrese istoričara medicine. Do 2020. održano je 11 kongresa. U radu četiri kongresa učestvovali su i istoričari medicine iz Slovačke, Rusije, Poljske, Crne Gore i BiH, tako da su ti kongresi bili akreditovani kao "nacionalni kongresi sa međunarodnim učešćem”. U periodu od 2009. do kraja 2020. godine, Sekcija je održala 193 naučna ili stručna skupa (11 kongresa, pet simpozijuma, jedan kurs i 176 sastanaka) na kojima je 229 autora saopštilo 698 radova, predstavljeno je 16 knjiga i prikazano 19 dokumentarnih filmova iz oblasti istorije medicine.

U saradnji sa Ambasadom Republike Poljske, u dvorištu SLD, 8. juna 2017. godine, svečano je otkrivena bista profesora Ludvika Hiršfelda (1884-1954), rad akademskog vajara Gorana Čpajka. Na predlog Sekcije, Javno preduzeće „Pošta Srbije” objavilo je seriju od šest poštanskih maraka sa likovima tri srpska lekara iz Prvog svetskog rata (dr-a Vojislava J. Subbotića, Mihajla Petrovića i Miloša Đ. Popovića) i tri inostrana lekara (dra Edvarda Rajana, Vilijama Hantera i Ludvika Hiršfelda), kao i tri koverta prvog dana, u čast završetka Velikog rata [27] (Slika 3).

Sekcija za istoriju medicine SLD je u periodu od 2009. do 2020. imala bogatu izdavačku delatnost. Objavljeni su zbornici radova saopštenih na deset održanih kongresa istoričara medicine, koji se organizuju pod zajedničkim nazivom 800 godina srpske medicine, zbornici radova sa simpozijuma i sastanaka sekcije posvećenim značajnim lekarima i događajima iz naše prošlosti (dr Laza K. Lazarević, dr Emerih P. Lindenmajer, dr Svetislav Stefanović, dr Aćim Medović, prof. dr Leon Kojen, 80 godina Stomatološke sekcije Srpskog lekarskog društva), Izveštaj o radu Sekcije za istoriju medicine SLD whose President, at the time, was Dr. Budimir Pavlović. Since the Section had not submitted any reports on its work nor did it have active members for years, the Governing Board of the SMS decided, on September 24, 2004, to close down the Section if it did not start with activities. Although it still did not operate, the Section was not terminated.

The fourth period of the Section's history began in 2009 and is still ongoing. As the newly elected President of the SMS (January 31, 2009), Professor Radoje Čolović made the decision to renew the work of "inactive sections and branches". On the initiative to restore the Section for the History of Medicine, Professor Brana Dimitrijević wrote the following in his book Moja geri$1 a^{18}$ : "At the end of January or the beginning of February 2009, I received a telephone call from Professor Radoje Čolović, PhD, associate member of the Serbian Academy of Sciences and Arts. He told me that he had become the President of the Serbian Medical Society and that he was willing to renew the work of the inactive sections, including the Section for the History of Medicine. He requested from the writer of these lines to take upon himself the duty of President of that section and to gather people as members." [26]. The meeting organized with the aim to renew the activity of the Section was held on March 19, 2009, and all the doctors who were known to be involved or interested in the history of medicine were invited to attend. The turnout was beyond all expectations. The Governing Body was elected at this meeting by acclamation - Professor Brana Dimitrijević for President - and the decision was made to hold meetings eight times a year with a minimum of two communications per meeting. Professor Čolović

\footnotetext{
18 Translator's note: Title translation - My Guerilla
} 


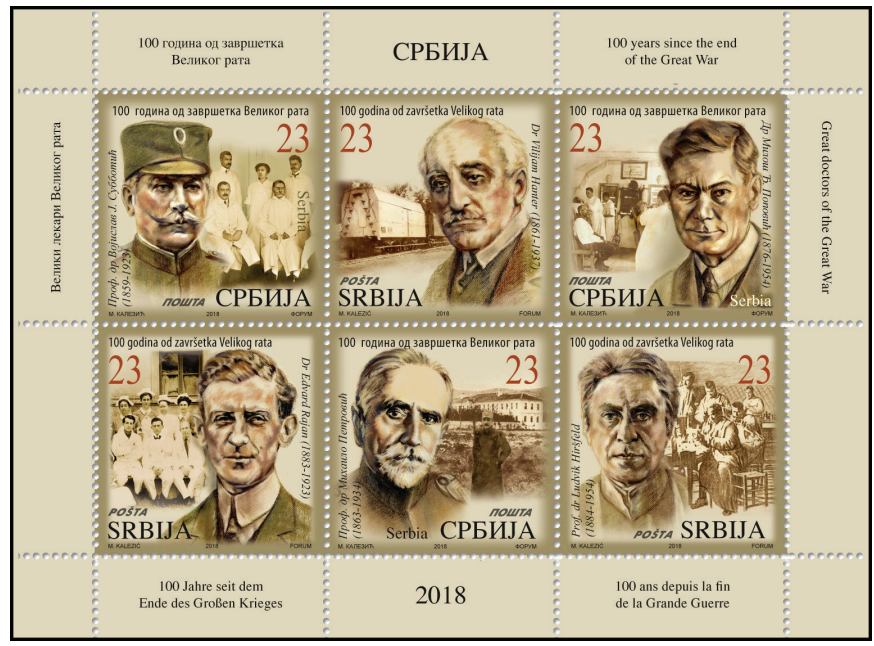

Slika 3. Emisija poštanskih maraka 100 godina od završetka Velikog rata - Veliki lekari Velikog rata (Izvor: JP Pošta Srbije)

Photo 3. One hundred years since the ending of the Great War - Great doctors of the Great War postage stamp commemorative series (Source: Public Enterprise Pošta Srbije)

(6. jun 2015 - 7. jun 2019) i knjiga Dr Milan Pecić - autobiografija najstarijeg pukovnika srpskog saniteta (2020).

Sekcija je dve godine zaredom, 2016. i 2017, bila dobitnik Nagrade za najbolju sekciju Srpskog lekarskog društva.

Danas je Sekcija za istoriju medicine Srpskog lekarskog društva jedina organizacija u Srbiji koja se sistematski bavi istraživanjima u oblasti istorije srpske medicine, organizovanjem kongresa, simpozijuma i naučnih i/ili stručnih sastanaka u ovoj oblasti, publikovanjem radova saopštenih na skupovima koje organizuje. U radu Sekcije, pored lekara, stomatologa i farmaceuta, učestvuju veterinari, istoričari, istoričari umetnosti, bibliotekari, filolozi, i dr. Zahvaljujući njihovom učešću ostvaruje se multidisciplinarni pristup izučavanju istorije srpske medicine od srednjeg do kraja XX veka.

\section{ZAKLJUČAK}

Od osnivanja 1872. do 1922. godine, Srpsko lekarsko društvo nije u svom sastavu imalo specijalističke sekcije. Pravni osnov za osnivanje sekcija predstavljale su izmene Pravila SLD, usvojene 1919. godine na 41. glavnom godišnjem skupu SLD. U međuratnom periodu (1918-1941), u Srpskom lekarskom društvu osniva se sedam sekcija.

Posle Drugog svetskog rata počinje sa radom veći broj sekcija. Sekcija za istoriju medicine i farmacije SLD osniva se 12. februara 1950. godine. Sanitetski general, profesor dr Vladimir Stanojević izabran je za predsednika Sekcije, a za počasnog predsednika „izabran je nestor naših mediko-istoričara" dr Risto Jeremić. then went on to deliver a lecture titled Dr Aćim Medovic - prvi predsednik Srpskog lekarskog društva (1872). ${ }^{19}$

Professor Dimitrijević was at the head of the Section until the Third Election Assembly, held on June 6, 2015, when Dr. Zoran Vacić, who was until then a member of the Governing Body, was elected President of the Section. On June 7, 2019, at the Fourth Election Assembly, in Novopazarska Banja, he was reelected for another four-year term (Photo 2).

As of 2010, the Section has been organizing regular annual congresses of historians of medicine. There were 11 congresses held until the year 2020. Historians of medicine from Slovakia, Russia, Poland, Montenegro and Bosnia and Herzegovina were participants of the four congresses, which is why they were accredited as "national congresses with international participation" Between 2009 and the end of 2020, the Section held 193 scientific or professional gatherings (11 congresses, 5 symposiums, one course and 176 meetings) where 229 authors presented 698 papers, 16 books and 19 documentary films in the field of the history of medicine.

In cooperation with the Embassy of the Republic of Poland, on June 8, 2017, in the courtyard of the Serbian Medical Society, a ceremony was held to uncover the bust of Professor Ludwig Hirszfeld (1884 - 1954), by the sculptor Gorana Čpajk. At the proposal of the Section for the History of Medicine, the Public Enterprise Pošta Srbi$j e^{20}$ issued a series of six postage stamps with portraits of three Serbian doctors from World War I (Dr. Vojislava J. Subbotić, Dr. Mihajlo Petrović, and Dr. Miloš Đ. Popović) as well as portraits of three foreign doctors, from that period (Dr. Edward Ryan, Dr. William Hunter, and Dr. Ludwik Hirszfeld), as well as three first day covers, to commemorate the ending of the Great War [27] (Photo 3).

Between 2009 and 2020, the Section for the History of Medicine of the SMS had a fruitful publishing period. In that period the following were published: books of proceedings with papers from 10 congresses of historians of medicine, organized under the umbrella title 800 Years of Serbian Medicine; books of proceedings with papers presented at symposiums and Section meetings dedicated to prominent doctors and significant events of the Serbian past (Dr. Laza K. Lazarević, Dr. Emmerich P. Lindenmayer, Dr. Svetislav Stefanović, Dr. Aćim Medović, Professor Leon Kojen, PhD, $80^{\text {th }}$ anniversary of the Section for Stomatology of the Serbian Medical Society); the report Izveštaj o radu Sekcije za istoriju medicine SLD (6. jun 2015 - 7. jun 2019)21; and

19 Translator's note: Title translation - Dr. Aćim Medović - First President of the Serbian Medical Society (1872)

20 Translator's note: Post of Serbia

21 Translator's note: Title translation - Report on the Work of the Section for the History of Medicine of the SMS (June 6, 2015 - June 7, 2019) 
Sekcija je u proteklih 70 godina svog postojanja beležila uspone i padove. Prvi period izuzetno plodnog rada trajao je od osnivanja 1950. godine do smrti prvog predsednika, profesora Vladimira Stanojevića (1978). U drugom periodu, koji traje od 1978. do 1993. godine, rad Sekcije gubi na intenzitetu. Sekcija je 1980. godine promenila ime u Sekcija za istoriju medicine. Održana su 22 sastanka na kojima su saopštena 34 rada. Treći period, od 1993. do 2009. godine je period potpune neaktivnosti Sekcije.

Četvrti period rada Sekcije počeo je 2009. godine i traje do danas. Na inicijativu predsednika SLD, profesora Radoja Čolovića, obnovljen je rad Sekcije Izbornom skupštinom održanom 19. marta 2009. godine. Za predsednika Sekcije izabran je profesor Brana Dimitrijević. Profesor Dimitrijević bio je na čelu Sekcije do Treće izborne skupštine 6. juna 2015. godine, kada ga je na ovom mestu zamenio dr Zoran Vacić, dotadašnji član Predsedništva, kome je na Četvrtoj izbornoj skupštini, održanoj u Novopazarskoj Banji, 7. juna 2019. godine, mandat produžen za još četiri godine. Počev od 2009. do 2020. Sekcija je održala 193 naučna ili stručna skupa na kojima je 229 autora saopštilo 698 radova, predstavljeno je 16 knjiga i prikazano 19 dokumentarnih filmova iz oblasti istorije medicine. Objavljeno je 18 zbornika radova, monografija i/ili izveštaja.

Uspešnost rada Sekcije za istoriju medicine u proteklih sedam decenija sagledavamo kroz realizaciju zadataka koje su postavili osnivači 1950. godine. Dva tada postavljena cilja nisu u potpunosti ostvarena. Prvi je izrada bibliografije srpske medicinske književnosti. Članovi Sekcije su, pišući biografije naših lekara, navodili i njihove bibliografije, međutim, to je parcijalni rad. Pokazalo se da Sekcija nije imala snage da izradi celovitu bibliografiju srpske medicinske književnosti. Drugi zadatak, koji nije ostvaren u potpunosti, jeste osnivanje katedri za istoriju medicine (stomatologije) na srpskim medicinskim fakultetima i Stomatološkom fakultetu. Međutim, iako nisu ustanovljene posebne katedre, u nastavnim programima su istorija medicine $\mathrm{i}$ istorija stomatologije zastupljene kao izborni predmeti.

Druge zadatke članovi Sekcije su ili realizovali (osnivanje Muzeja Srpskog lekarskog društva) ili kontinuirano rade na njihovoj realizaciji (obrada arhivske građe; buđenje interesovanja za istoriju medicine u široj javnosti; multidisciplinarni pristup izučavanju istorije medicine, stomatologije i farmacije).

$\mathrm{Na}$ osnovu rezultata rada može se zaključiti da je rad Sekcije za istoriju medicine bio uspešan i da je većina zadataka koje su osnivači postavili realizovana. U prilog ovoj tvrdnji idu nagrade za najbolju sekciju Srpskog lekarskog društva 2016. i 2017. godine. the book Dr. Milan Pecić - autobiografija najstarijeg pukovnika srpskog saniteta ${ }^{22}$ (2020).

Two years in a row, 2016 and 2017, the Section received the Award for Best Section of the Serbian Medical Society.

At present, the Section for the History of Medicine of the Serbian Medical Society is the only organization in Serbia which is systematically involved in: research in the area of the history of Serbian medicine; organizing congresses, symposiums and scientific and/or professional meetings related to the history of medicine; publishing papers presented at the gatherings organized by the Section. In addition to doctors, dentists and pharmacists, veterinarians, historians, art historians, librarians, philologists, and other profiles are involved in the work of the Section. Thanks to their participation, a multidisciplinary approach to the study of the history of Serbian medicine from the Middle Ages to the end of the $20^{\text {th }}$ century is being applied.

\section{CONCLUSION}

Since its founding, in 1872, until 1922, the Serbian Medical Society did not have any specialist sections within its organizational structure. The legal framework for establishing the sections was founded in the amendments to the Rules of the SMS which were adopted at the XLI General Assembly, held in 1919. In the interwar period (1918-1941), seven sections were formed within the Serbian Medical Society.

After World War II numerous sections were formed. The Section for the History of Medicine and Pharmacy of the SMS was formed on February 12, 1950. Medical Corps General, Professor Vladimir Stanojević was elected President, while "Dr. Risto Jeremić, the sage of our medical historians" was appointed Honorary President.

During the past 70 years of its work, the Section has had periods of rise and fall in its activity. The first period of very fruitful work lasted from the forming of the Section, in 1950, until the death of its first President, Professor Vladimir Stanojević, in 1978. In the second period (1978 - 1993), the work of the Section lost momentum. In 1980, the Section changed its name to the Section for the History of Medicine. 22 meetings were held, and 34 papers were presented at these meetings. The third period (1993-2009) was a period of complete inactivity of the Section.

The fourth period of the Section's history began in 2009 and is still ongoing. At the initiative of the President of the SMS, Professor Radoje Čolović, the work of the Section was renewed at the Election Assembly

22 Translator's note: Title translation - Dr Milan Pecić - Autobiography of the Oldest Colonel of the Serbian Medical Corps 
held on March 19, 2009. Professor Brana Dimitrijević was elected President. He remained President until the Third Election Assembly, held on June 6, 2015, when Dr. Zoran Vacić, who, until then had been a member of the Governing Body, succeeded him. On June 7, 2019, at the Fourth Election Assembly in Novopazarska Banja, he was reelected for another four-year term. Between 2009 and 2020, the Section held 193 scientific or professional gatherings where 229 authors presented 698 papers, 16 books and 19 documentary films in the field of the history of medicine. Also, 18 books of proceedings, monographs and/or reports were published.

The success of the activity of the Section for the History of Medicine in the past seven decades is reflected in its achievement of the objectives set forth by the founders in 1950. Two of the objectives defined at the time have not completely been met. The first is writing the bibliography of Serbian medical literature. While members of the Section, when writing biographies of our doctors, did provide lists of their published work, this remains only a partial achievement. It transpires that the Section did not have the capacity to write a complete bibliography of Serbian medical

\section{LITERATURA I IZVORI / REFERENCES AND SOURCES}

1. XXXV Glavni godišnji skup - 23. i 24. septembar 1907. u Kragujevcu. Srpski arhiv za celokupno lekarstvo, XIII (1907), 11:509.

2. Zapisnik 44. redovne godišnje skupštine Srpskog lekarskog društva držane 22. i 23. septembra 1922. u Beogradu. Srpski arhiv za celokupno lekarstvo. XXIV (1922), 8-12:419.

3. Zapisnik 50. godišnje skupštine Srpskog lekarskog društva održanog 6. septembra 1928. godine. Srpski arhiv za celokupno lekarstvo. XXX (1928), 12:1058, 1060.

4. Zapisnik XLI Glavnog godišnjeg skupa Srpskog lekarskog društva držanog 22. novembra 1919. godine. Srpski arhiv za celokupno lekarstvo. XXII (1920), 1-2:100.

5. Službene Novine Kraljevstva Srba, Hrvata i Slovenaca. I (16. novembar 1919.). 114: 2.

6. Službene Novine Kraljevine Srba, Hrvata i Slovenaca. III (27. decembar 1921.), 290: 4, 5.

7. 43. Glavni godišnji skup održan 3. i 4. septembra 1921. godine. Srpski arhiv za celokupno lekarstvo. XXIII (1921), 10:547, 549.

8. Ustav Srpskog lekarskog društva. Srpske Novine. XXXIX (25. jula 1872), 88:520.

9. XLV godišnji skup Srpskog lekarskog društva održan 14. i 15. septembra 1923. godine. Srpski arhiv za celokupno lekarstvo. XXV (1923), 11:533.

10. Zapisnik I red. sastanka Sekcije Srpskog lekarskog društva za dečiju medicinu, održan 16. XII 1925. godine. Srpski arhiv za celokupno lekarstvo, XXVIII (1926), 7:373.

11. Zapisnik 50. Glavnog godišnjeg Skupa Srpskog Lekarskog Društva. Srpski arhiv za celokupno lekarstvo. XXX (1928), 12:1058.

12. 52. godišnja skupština Srpskog lekarskog društva održana 30. septembra 1930. godine. Srpski arhiv za celokupno lekarstvo. XXXII (1930), 12:1049.

13. 54. godišnja skupština Srpskog lekarskog društva održana 22. septembra 1932. godine. Srpski arhiv za celokupno lekarstvo. XXXIV (1932), 10:812. literature. The second task has not been completely achieved, this being the establishing of the Department for the History of Medicine (Stomatology) at the faculties of medicine and stomatology in Serbia. However, although separate departments have not been established, the history of medicine and stomatology are offered within the curriculum of these faculties, as elective courses.

The members of the Section have achieved the remaining objectives (founding of the Museum of the Serbian Medical Society) or are continuously working on their realization (processing of archive material; raising awareness and interest in the history of medicine amongst the public; applying a multidisciplinary approach to the study of the history of medicine, stomatology and pharmacy).

Based on the results achieved, one can conclude that the work of the Section for the History of Medicine has been successful and that most of the objectives set by the founders have been met. The fact that the Section received awards for the best section of the Serbian Medical Society in 2016 and 2017 speak to this effect.

14. Zapisnik 56. godišnjeg skupa Srpskog lekarskog društva održanog na dan 25 . novembra 1934. Srpski arhiv za celokupno lekarstvo. XXXVI (1934), 12:938.

15. Zapisnik 50. Glavnog godišnjeg skupa Srpskog Lekarskog Društva. Srpski arhiv za celokupno lekarstvo. XXX (1928), 12:1058.

16. 53. godišnja skupština Srpskog lekarskog društva održana 15. septembra 1931. godine. Srpski arhiv za celokupno lekarstvo. XXXIII (1931), 10:848, 855.

17. Izveštaj Upravnog odbora Srpskog lekarskog društva podnesen 68. redovnoj godišnjoj skupštini 25. marta 1951. godine. Beograd: Naučna knjiga, 1951, 90.

18. Jovanović Simić J. Muzealizacija medicine: muzeji i zbirke u Srbiji. Beograd: Muzej nauke i tehnike. 2019, 195.

19. Sednica 9. decembra 1949. godine. Srpski arhiv za celokupno lekarstvo. XLVIII (1950), 3:249.

20. Izveštaj Upravnog odbora Srpskog lekarskog društva podnesen 68. redovnoj godišnjoj skupštini 25. marta 1951. godine. Beograd: Naučna knjiga, 1951, 36.

21. Iz rada Sekcija SLD. Srpski arhiv za celokupno lekarstvo. XLVIII (1950), 6:467.

22. Kostić A. 0 jednom stogodišnjem srpskom medicinskom leksikonu. Iz istorije medicine. Srpski arhiv za celokupno lekarstvo. XLVIII (1950), 6:456-62.

23. Jeremić R. Peičić, d-r Konstatin. U Prilozi za biografski rečnik Srba lekara Vojvođana 1756-1940. Novi Sad: Medicinski pregled, 103-5.

24. Jeremić R. Bibliografija srpske zdravstvene književnosti 1757-1918. Beograd: Srpsko lekarsko društvo. 1947.

25. Izveštaj o radu Sekcije za istoriju medicine SLD - za period 1983-1986. Muzej nauke i tehnike - Zbirka Muzeja srpske medicine SLD.

26. Dimitrijević B. Moja gerila. Beograd: Infinitas. 2010, 278.

27. Vacić Z. Izveštaj o radu Sekcije za istoriju medicine Srpskog lekarskog društva (6. jun 2015 - 7. jun 2019). Beograd: Srpsko lekarsko društvo. 2019, 5-9. 